\title{
The Story of Colonialism, or Rethinking the Ox-Hide Purchase in Native North America and Beyond
}

Jason Baird Jackson

Published as Jason Baird Jackson (2013) The Story of Colonialism, or Rethinking the Ox-Hide Purchase in Native North America and Beyond. Journal of American Folklore. 126(499):31-54. (C) 2013 by the Board of Trustees of the University of Illinois.

This publishers version is posted in an green open access form under the terms of the American Folklore Society "Author Deposit Permissions Policy" in effect at the time of publication. As noted in that policy: "Authors may post publisher's versions of their JAF contributions to the repository of their home institution as soon as those versions are available. When posting a publisher's version, authors must include one of the following two notations:

For JAF contributions published before 2003:

Published as [provide the complete bibliographic citation as it appears in the print version of the Journal of American Folklore]. ( ) [Year] by the American Folklore Society.

For JAF contributions published beginning in 2003:

Published as [provide the complete bibliographic citation as it appears in the print version of the Journal of American Folklore]. ( [Year] by the Board of Trustees of the University of Illinois."

http://www.press.uillinois.edu/journals/jaf/jafdeposit.html, accessed March 9, 2013.

Scholars, teachers, and other interested parties who have paid-for access to Journal of American Folklore content are encouraged to support the American Folklore Society and utilize such access.

This paper is accessible via ProjectMuse (DOI: 10.1353/jaf.2013.0004) at:

http://muse.jhu.edu/journals/journal_of_american_folklore/v126/126.499.jackson01.html

This paper is accessible via JSTOR (DOI: 10.5406/jamerfolk.126.499.0031) at:

http://www.jstor.org/stable/10.5406/jamerfolk.126.499.0031 
JASON BAIRD JACKSON

\section{The Story of Colonialism, or Rethinking the Ox-Hide Purchase in Native North America and Beyond}

In this paper I offer a comparative assessment of the ox-hide purchase narrative (tale type AT 2400, ATU 927C*; Motif K185.1) in Native North America. Drawing on my own fieldwork and the beginnings of a historic-geographic treatment, I consider the story from the perspective of work on historical consciousness in Native North America and treat it as an opportunity to establish a link between folkloristics and other fields concerned with interpreting the legacies of colonialism.

Colonialism generated space for many kinds of new oral discourses: the colonisers talking about the colonised (which is largely known and studied) and the colonised talking about the colonisers. The later area of research remains almost untouched.

-Sadhana Naithani (2004)

DESPITE LIVING IN A WORLD of rapid global communication, some apparent diffusions, or as we might say in the idiom of our era, some global cultural flows still surprise us. ${ }^{1}$ A number of Native North American peoples tell a story that is best known among scholars as a motif from the legend of the founding of ancient Carthage by Dido. Identified by comparative folklorists as both a tale type (AT 2400, ATU 927 $\mathrm{c}^{\star}$ ) and a motif (K185.1), the story features colonists who trick the local inhabitants by asking for only as much land as can be measured with one ox-hide. Given the small size of a single hide, the locals agree, and then the colonizers proceed to cut it into a fine string with which they encircle much more land than was envisioned by the locals. Such stories are told as history, with different inflections, by groups whose ancestors were both the clever perpetrators and the honest victims of this fraud. While the presence of this story in the narrative repertoires of American Indian peoples has been generally known since at least the nineteenth century, it has not been comparatively examined in the Americas, in contrast to the rest of the world, where it has been taken up by a long line of distinguished scholars (Köhler 1864:187, 1900:321). In this paper I offer a comparative assessment of the ox-hide purchase in Native North America. Working outward from my own fieldwork experiences and the beginnings of a historic-geographic treatment, I seek to consider the story from both the perspec-

JASON BAIRD JACKson is an Associate Professor of Folklore and American Studies at Indiana University

Journal of American Folklore 126(499):31-54

Copyright $\odot 2013$ by the Board of Trustees of the University of Illinois 
tive of recent work relating to historical consciousness in Native North America and as a chance to establish an additional link between folkloristic studies of narrative and research in other fields more closely concerned with understanding the legacies of colonialism. ${ }^{2}$

\section{"The Coming of the White Man"}

In Huron and Wyandot Mythology, the rich collection of oral narratives that the industrious Canadian folklorist Marius Barbeau (1915) gathered among these kindred but sundered peoples, we find a straightforward text that can open up the topic of this paper. Titled by Barbeau, if not by his narrator, "The Coming of the White Man," it was told to him in English in June of 1911 by Mary McKey, a seventy-three-year-old Wyandot of the Bear clan then living in Amherstburg, Ontario (Barbeau 1915:xi, 271, 425). ${ }^{3}$ As reported by Barbeau, this story, from among the Canadian Wyandot, goes as follows:

When the white man was first seen here, in the old time, he began to barter with our ancestors. Nowhere could he step without coming across some red man, [all the land being occupied].

The stranger came forth with a cow's hide, saying that he wanted a piece of land. The Indian, thinking that it was all about a piece of land the size of a cow's hide, agreed to the barter. The other fellow, however, cut the cow's hide into a string [wherewith to measure a large domain]. The Indian remarked, "This is the way the white man does. He cheats the Indian." And he had to give away the land which the string had measured. (Barbeau 1915:271)

Ms. McKey's version, like those I have been told among the Woodland Indian peoples of Oklahoma, takes a motif and makes a compressed, stand-alone story out of it. It is this kernel of narrative, known to comparative folklorists by the new tale type number ATU $927 C^{*}$, that is the focus of this paper (see Uther 2004:566-7; previously it was type AT 2400, see Aarne and Thompson 1981:539). ${ }^{4}$ For purposes of this project, I will follow the custom of the Woodland Indian peoples among whom it is told, and label the narrative a story. This less-specific emic label enables me to evade several typological questions that might hinder the analysis that I aim to pursue. The folklorist's impulse might be to begin by treating that narrative as a legend, but among Woodland Indian people, the diffuse genre category story shifts responsibility for assigning truth value away from narrators and onto listeners, a process that now encompasses readers of this paper (see Jackson 2003:206; Linn and Jackson 2004; Urban and Jackson 2004). For now, it is enough to note that Ms. McKey's version is a token of the story's simplest type. For ease of reference, I will call it by the catchword "The Ox-Hide Purchase."

A year later, in June 1912, Barbeau was privileged to record another version, this time at Wyandotte, Oklahoma. The narrator from among the Oklahoma Wyandots was John Kayrahoo, a seventy-two-year-old member of the Porcupine clan who was a monolingual Wyandot speaker (Barbeau 1915:xi, 268-70). Mr. Kayrahoo's narrative is embedded within a larger story that elaborates further on the phenomena of "first contacts" in the Eastern Woodlands of North America. ${ }^{6}$ His account begins by noting 
that the Wyandot, at the time that they first met Europeans, led an intertribal league in which the Delaware (also known by their ethnonym Lenape) "occupied the second rank." As the most coastal of its peoples, the Delaware were charged with guarding the shore and preventing any landings. ${ }^{7}$ In this context, Europeans arrive in startling "cloud-like" ships, and the astonished Delaware fail to prevent them from anchoring. The Delaware are invited aboard and are offered a rich array of heretofore-unknown manufactured goods. Echoing many of the known Delaware narratives on the same theme, the Wyandot version devotes rich attention to recounting the amusing experiments undertaken with these new goods. Particularly appealing to narrators up to our own day is the image of iron ax heads that were mistakenly worn as necklace pendants rather than used as tools (cf. Bierhorst 1995, numbers 17, 22, 28, 40, 83, 203, 215; Rementer 2005). ${ }^{8}$ In the Wyandot account, this episode ends in a moment of sincere friendship that is then broken with the ox-hide purchase incident (Barbeau 1915:268-9).

Mr. Kayrahoo's account of these early days continues as follows:

Then it happened that the white man wanted to purchase some land, that is, just the size of a cow's hide. The Delaware chiefs considered the matter, and agreed to grant the request, as a cow's hide was a small thing. The white man, moreover, could occupy but a small strip of land, since there were so many of them crowded on their ship, as if it had been a village. ${ }^{9}$

No sooner had the Indians signified their acceptance than the white men looked for the largest bull in their possession and killed it. Stretching the skin as much as they could, they cut it up into a tiny string. They went to see their Indian friends and informed them that they were ready. And then, with the string, they measured a large body of land by going around it. The Delaware at once objected that this was not the proposition which he had accepted, for he would not give more than the size of a cow's hide.

As it was done, however, the Delawares sent messengers to the Wyandots who were traveling in the western lands. As they came back, the Wyandots were astonished to find so many white people among the Delawares, and asked their friends what authority they had to let anybody thus intrude [on the Indian's] land, in their allies' absence. The Delaware replied to the Wyandot that it could not be helped. The white man had offered him everything he had and had been so good to him that he could not refuse him just the size of a cow's hide of land. ${ }^{10}$ The Wyandot, having learnt how the stranger had cut the hide into a string, spoke in these terms, "So it is, and so shall it always be! The white fellow shall always undermine the Indian until he has taken away from him his last thing." (Barbeau 1915:269-70)

In the final sentence of this section, Mr. Kayrahoo strives to make clear that this reported speech, the only direct discourse attributed to a native speaker, is prophecy. He states, "This was a kind of prediction." 1

In the remainder of the story, the Wyandot protest strongly against the Europeans, but to no benefit. According to Mr. Kayrahoo (Barbeau 1915:270), "[b]ut it was of no avail, trouble and wars began. The white man was an invader, and the Indian was determined to defend his rights. The Wyandots found several tribes of Indians ready to unite and declare war upon the invader." ${ }^{2}$ The urge to quote now completely over- 
powers my drive for economical presentation. Mr. Kayrahoo concludes his remarkable account as follows:

So a terrible war followed. The white man, as a last resort, used a disease germ against [his enemy]. When he saw the wind blowing towards the Indian, he uncorked the bottle in which the smallpox germs were kept and he let them run out. Overpowered by this calamity, the Indian had to come to terms, and he shook hands with him to show that they were to live together in peace. ${ }^{13}$ After a compact had been reached, the white chief spoke to the Wyandot chief, saying, "Hereafter all the lands that I have purchased from the Delaware shall be mine and I will proceed to occupy them. We shall forever be friends and we must not refer to the past war between us. We shall, moreover, be your guardians and look after your business." (Barbeau 1915:270)

With these words of the white chief, occurring in the story's only other moment of direct reported speech, Mr. Kayrahoo brings the story to a close, again offering an explanation of perfect clarity. He ends noting: "The meaning of this was that the Indians had now fallen under the conqueror's government. The old-time saying has long been handed down among us, that we must adopt the white man's way, because we are now in his clutches" (Barbeau 1915:270). ${ }^{14}$

Before examining the ox-hide story comparatively, I wish to make one discoursecentered observation on it. In Mr. Kayrahoo's account, I noted the two moments of direct reported speech: the first, the words of the Wyandot chief; the second the words of the white chief. Both were offered as prophecy. If we permit them to be set, as the narrator intended, in the appropriate temporal frame, the Wyandot prophecy has certainly proven true, while that of the white chief is poignantly untrue. Mr. Kayrahoo's own commentary is so clear, one can almost hear his own voice in all of this. One can perhaps also picture a mental image of Barbeau the young fieldworker. The story ends categorically, with the phrase "we are now in his clutches." Having experienced many moments like this as a naïve young white ethnographer in the company of thoughtful, complex old Indian men, I can only imagine there were a few moments of respectful silence before someone made a joke and changed the topic, to the unpredictable Oklahoma weather, perhaps. $^{15}$

\section{Comparisons, Old and New}

Having shared, in paraphrase and quotation, the texts that he collected, I owe Barbeau the first chance to comment upon them. In a note to Mr. Kayrahoo's text, he wrote: "The above tradition is really a parable. It is difficult to see exactly to what historical facts it refers. In fact, it seems to characterize in a symbolic manner the whole problem of spoilation of the Indian's rights by the white invader" (1915:268n3). I am not going to disagree with Barbeau in this view. Instead I will try to take up, and elaborate, this reading, but first I would note that, for its day, this was a rather sophisticated, reflexive frame within which to place the text.

While Barbeau did not cite the comparative literature on the ox-hide purchase as it then existed, he did acknowledge its presence in European tradition. He reported 
an English version told to him by one of his colleagues at the Canada Geological Survey. ${ }^{16}$ This version, set somewhere in the north, accounted for British colonization of Ireland or Scotland. In his general discussion of Wyandot mythology, Barbeau also offers one of the few historical interpretations by an Americanist on the ox-hide purchase, suggesting: "Although the Europeans might have borrowed it from the Indians, it is more probable that the latter heard it from the neighboring European settlers here and embodied it in their own narratives" (Barbeau 1915:26-7). ${ }^{17}$

Despite being required to read the primary works of James Frazer as an anthropology student at Oxford University, Barbeau seems not to have fully made the connection between the Wyandot ox-hide purchase (with its English analog) and the European and Asian tradition that had already become a matter of scholarly discussion (Barbeau 2006). The story is best known among scholars as a motif from the legend of the founding of ancient Carthage by Dido, as narrated by Virgil in the Aeneid and explicated by other writers from antiquity to the present. It is this association that has generated a rich (and vast), if sometimes strange, bibliography for the story and, for our purposes, is a fact that possibly also opens up new lines of cross-disciplinary dialogue (Virgil 1995; see also Rose 1929:309). ${ }^{18}$

While relevant works preceded it, a convenient point of entry for the older literature, at least for an English-speaking anthropological folklorist, is Frazer's 1888 contribution to the Classical Review, a short note titled "Hide Measured Lands." In it, he cites Virgil on Didos founding of Carthage and then builds upon work by Jacob Grimm (1881) and Reinhold Köhler (1864), by noting, and summarizing, five additional cognate texts culled from the literature: one each from the Tatar, Burma, Cambodia, Java and Bali. ${ }^{19} \mathrm{He}$ concludes by claiming: "The wide diffusion of such tales confirms Grimm's conjecture (Grimm 1881:538) that in them we have a recollection of a mode of land measurement once actually in use and of which the designation is still retained in the English hide" (Frazer 1888:322; see also Oxford English Dictionary, "hide": n2). This is classic Frazer, of course: fascinating, sweeping generalization sprung almost instantly out of a rich ingathering of decontextualized, but global, particulars. Subsequent work has undermined the philological underpinnings of Frazer's (and Grimm's) survivalist argument concerning the measurement of land, but the texts noted did make clear that a phenomenon of worldwide interest was under discussion.

While the entire history of research on the ox-hide purchase is beyond my scope here, a second dip into the bottomless well of Frazer's comparative thinking on such matters will prove fruitful. In his best-known work, the twelve-volume collection titled The Golden Bough, Frazer offers further discussion of the ox-hide purchase. In this study, he found the story's deeper rationale in a Bantu charm used to protect a new town from witchcraft. This Bechuanas rite involved the sacrifice of a sacred cow whose eyes had been sewn shut for four days prior to being, on the fifth day, ceremonially killed and ritually feasted upon. Afterwards, the hide was cut into two-foot strips, which, having been prepared by specialists, were taken by messengers in all directions and were pegged down in the roads leading to the new town. In Frazer's understanding of Rev. W. C. Willoughby's (1905) ethnographic account, the Bechuanas town was then protected through its ritual encompassment by one of the people's sacred cattle (Frazer 1935:249-50). ${ }^{20}$ 
For Frazer, the Bantu rite and the ox-hide purchase both deal with the founding of new settlements and involve ritual encompassment of the site by a hide. In this later work, Frazer retains Grimm's belief that ancient systems of measurements are at issue here, but he goes further to argue that these techniques, at a deeper level, were born of the principles reflected in the South African ritual, namely, "that the mode of measuring by a hide may have originated in a practice of encompassing a piece of land with thongs cut from a hide of a sacrificial victim in order to place the ground under the guardianship of the sacred animal" (Frazer 1935:249-50). ${ }^{21}$

Frazer's doubtful (for modern readers, at least) take is not the only one that a fuller history of research on the ox-hide purchase would need to confront. The literature, for the Occident and for the Orient, is substantial. Changing scholarly thinking on it is a mesmerizing topic, one that speaks to larger issues in the history of knowledge and knowledge production, among other things. In reflecting upon Frazer's contribution to the larger literature, I would only note, beyond simply observing that later work has sharply criticized the philological basis of his measurement argument, that the small sample that Frazer offers contains an interesting pattern (Powell 1933:311). The Burmese case is a local legend in which a slave tricks the king to whom she is enslaved. The Balinese instance is a matter of "indigenous" colonialism, celebrating provincials who trick their own king. ${ }^{22}$ The Tartar case is situated within a context of Russian colonization of the East, while the Cambodian and Javanese examples speak to Western European colonialism, specifically in these two cases, that of the Dutch. In trying to offer us a reconstructive history of universal human ritual and law, Frazer has actually sketched the basis for a quite different comparative framework.

In developing a new scheme for thinking about this story, we might acknowledge that such narratives are told as history, with different inflections, by groups whose ancestors were both the clever perpetrators and the honest victims of this fraud. I suggest that we also note that the historical contexts that give the story meaning vary on a continuum from purely local trickery through more "internal," if no less unwelcome, forms of colonization to the specific instance of global European colonialism that shaped the formation of the modern capitalist world-system. These patterns, in a small way, might help us to begin conceptualizing a comparative folkloristics of colonial experience. Finally, while I, and the Native North American examples that I am most concerned with, place emphasis on the morality of the victims relative to the deviousness of the perpetrators, the story, as a type or a motif, exists within a wider, more complex framework where this aspect can cut both ways.

Frazer's Burmese and Balinese examples show this aspect, as they describe such tricks being used by clever, but subordinated, peoples against those who would rule them. ${ }^{23} \mathrm{~A}$ famous and accessible instance of this type, one that can also introduce a related motif (K185.7), in which the trick hinges on the land being marked by foot travel, is Leo Tolstoy's (1993) short story "How Much Land Does a Man Need?"24 In this story, written in emulation of oral folktales, Tolstoy tells of a Russian peasant who, driven on by the Devil through a series of ever-expanding land purchases, meets his end while seeking to trick a group of Bashkirs into selling him their rich and, to European eyes, underused lands. The Bashkir chief agrees to sell but explains that their going price is one thousand rubles a day. Confused, the peasant asks how land 
can be measured in days. The chief explains that, as they lack a system of measurement, the sale will encompass as much land as he can encircle on foot before sunset. When the process begins, greed pushes him to go for broke, and he arrives back at the starting point at sunset, only to collapse in death at the feet of the chief. I hope that my poor summary has not spoiled the story, which James Joyce pointed to as the best short story ever written. The title question is answered by the peasant's servant, who buries him far from home in a six-foot hole on the steppe where he fell (Tolstoy 1993; beyond assertions found widely on the Internet, one source on Joyce's praise for the story is noted in Ellmann 1983:227).

However much we might doubt their answer, Grimm and Frazer were not wrongheaded in taking up systems of measurement as a proper ethnological topic. Like the better-studied matter of systems of marking time, variable conceptions of measurement get to the heart of how cultures articulate people with the worlds in which they live (for time, see Dinwoodie 2006; for measurement, see Hallowell 1942). I also think that, from the perspective of classic comparative folkloristics, Frazer was justified in grouping (as Stith Thompson also did in the 1955-58 Motif Index and in his 1946 study The Folktale) instances of deception in the measurement of land under the same heading, as he did in the case of the Balinese legend that he cites in the company of the ox-hide purchase stories proper. In Frazer's summary, it goes as follows:

The people of Tengagan, a district in Bali, formerly enjoyed the honour of keeping the herds of the King of Kaloengkoeng. It befell that the King's riding horse died at pasture. So the King commanded that the horse should be buried on the spot and that the land, as far as the smell of the carrion spread, should belong to the herdsman. Thereupon the people of Tengagan cut the carcass in pieces and each of them sticking a bit in his girdle set off to walk. They walked and walked till they had as much land as they knew what to do with; and that is why the district of Tengagan is one of the biggest in Bali. (Frazer 1888:322 citing Eck 1880)

This text from Bali seems ready-made for a tourist brochure and, sure enough, one has no trouble finding Rutger van Eck's sketches of Bali, from which it derives, cited on the Web in pages catering to those travelers or would-be travelers wishing to partake of what James Boon characterized as The Anthropological Romance of Bali (1977). I include it here not to pull our attention further east, but to connect, as Frazer did, the ox-hide purchase with real estate deceptions undertaken on foot. This connection allows us to return to the Woodlands of North America and the people for whom we have the richest body of related texts and who, as Mr. Kayrahoo's story illustrates, can even take a starring role in versions told by other peoples.

Like the Wyandot, the Delaware peoples live today in diaspora-the product of an almost incomprehensibly complicated colonial history. The European-American side of this story tells of the forced displacement of the Delaware peoples westward from their homeland in present-day Delaware, New Jersey, New York, and Pennsylvania and can account for their fragmentation into communities found today in eastern Oklahoma, western Oklahoma, Wisconsin, and Ontario. Generations of ethnographers, in league with some remarkable Delaware tradition-bearers have, importantly, documented Delaware understandings of this experience, not only in the stories 
that are my concern here, but also the deeper conceptual issues at stake. Anthropologist Jay Miller in collaboration with Delaware elder Nora Thompson Dean has written of the Delaware concept of kwulakan, which, at the level of Delaware cosmology, characterizes how disagreement or conflict makes the land on which it unfolds dangerous. ${ }^{25}$ In essence, such land becomes contaminated by ill will, a fate that can also befall other forms of property. As Miller notes, this unfortunate process was, from a Delaware perspective, a factor that motivated Delawares to relocate westward to uncontaminated territories in the face of irresolvable conflict with those who colonized each of their successive homelands (Miller 1975; for a sketch of Delaware migrations since contact, see Goddard 1978).

In this context, we find that Delaware historical consciousness has proven hyperattentive to the story of first contact and the many colonial transformations that it spawned (Rementer 2005). Before exploring this, I need to address the story's distribution in the Americas. I have begun consulting relevant text collections, and I queried the nine hundred members of the Society for the Study of the Indigenous Languages of the Americas (SSILA) in search of versions (Jackson 2006). As scholars who generally know, with great familiarity, the text collections associated with the Native languages that they study, this seemed like, in the absence of a tale type index for Native North America, an efficient beginning. ${ }^{26}$ It is revealing that I only received negative responses from those studying languages other than Delaware, but three different scholars (Jim Rementer, Ives Goddard, and John Bierhorst) noted affirmatively the existence of Delaware texts. These are gathered in what is a model for Native North America, Bierhorst's Mythology of the Lenape: Guide and Texts (1995). Delaware first-contact stories are the special focus of Rementer's important contribution to the collection Algonquian Spirit: Contemporary Translations of the Algonquian Literatures of North America (2005).

Abstracting and indexing all known Delaware texts, Bierhorst identifies seven versions, the oldest a late eighteenth-century text collected by John Heckewelder from an unknown narrator, the most recent told by Ms. Bessie Snake of Oklahoma's Western Delaware community and collected by Jim Rementer and Bruce Pearson in 1978 (Bierhorst 1995, numbers 17, 215; Rementer 2005). ${ }^{27}$ These texts span both the full geographic range of the Delaware diaspora, from the Atlantic homeland to Canada and the Oklahoma groups, and the full history of ethnographic research relative to these communities. The texts are remarkably consistent across time, space, and narrators. All involve the ox-hide purchase motif, and most include many of the other associated motifs, including Native prophecy of European arrival, misunderstanding of European trade goods, initial experimentation with alcohol, and clear condemnation of European trickery. Two of the stories repeat the deception, adding a second incident in which additional land is obtained when the colonists ask for only as much land as a chair will cover. Upon securing agreement, they proceed to unwind the long cord comprising the chair's seat, which is used, as was the cowhide, to encircle a similarly large area (Bierhorst 1995, numbers 22,28$).{ }^{28}$

For Native North America, the ethnic distribution of the ox-hide purchase seems relatively limited. While told in modern times in both Eastern Canada and Eastern Oklahoma, its social history in the Woodlands seems clear-cut, and its far-flung 
distribution is probably attributable to the dispersal of a small number of allied groups, although it may, admittedly, be ancestral to a larger number of Woodland peoples for whom we have no recorded texts. It goes back among the Delaware, Shawnee, and Wyandot to a time before these peoples were sundered. ${ }^{29} \mathrm{We}$ also have published records of the story told among the Creek (Swanton 1928:75-7) and the Yuchi (Euchee) (Wagner 1931:156-64). ${ }^{30} \mathrm{I}$ have heard it told by personal friends among both the Yuchi and the Western Cherokee (see Jackson 2003:22, 294n10). These latter peoples, while conventionally viewed as being of the Southeastern Woodland, rather than Northeastern Woodland culture area, all belonged to a region-wide social network before the so-called "removal era," and this system was replicated in miniature in Oklahoma and, I am almost as certain, in Eastern Canada. While the history of these social contacts over time is complex, it is enough to note here that it is understood in outline and that there is a chain of social interaction that can be demonstrated to connect all the known communities where the story is told (Jackson 1999; Jackson and Fogelson 2004; Waselkov with Jackson 2004).

The most stunning of the reasons for dwelling on the Delaware case, both within this project and for any broader investigation of contact and colonization narratives in Eastern North America, is the fact that, in addition to possessing the richest body of narrative texts on these subjects, the Delaware also, uniquely it seems, experienced a similar incident that has also been recorded in the annals of documentary history in the Western mode. Several generations of professional historians have devoted attention to the so-called Walking Purchase, a fraudulent treaty between the Delaware and the Pennsylvania colony, which was conducted in $1737 .{ }^{31}$ The most eloquent and economical way of retelling this story is to quote the account of the event offered on the webpage of the Delaware Tribe of Indians..$^{32}$ This is the Delaware community settled in Eastern Oklahoma and the one that I am most acquainted with from my life and work in the region.

In Lenape history there is the story of the "Walking Purchase" which took place in 1737. William Penn had always dealt fairly with the Lenape, but after he returned to England his sons and other agents began to sell land to pay their creditors, and these were lands which were still owned by the Lenape.

In order to convince the Lenape to part with the land, the Penns falsely represented an old, incomplete, unsigned draft of a deed as a legal contract. They told the Lenape that their ancestors some fifty years before had signed this document which stated that the land to be deeded to the Penns was as much as could be covered in a day-and-a-half's walk.

Believing that their forefathers had made such an agreement the Lenape leaders agreed to let the Penns have this area walked off. They thought the whites would take a leisurely walk down an Indian path along the Delaware River. Instead, the Penns hired three of the fastest runners, and had a straight path cleared. Only one of the "walkers" was able to complete the "walk," but he went fifty-five miles.

And so by means of a false deed, and use of runners, the Penns acquired 1200 square miles of Lenape land in Pennsylvania, an area about the size of Rhode Island! The Lenape people complained about the way the "walk" had been done. Lenape chief Lappawinsoe expressed the frustration and dissatisfaction of the Lenape when 
he said: "[the white runners] should have walkt along by the River Delaware or the next Indian path to it . . . should have walkt for a few Miles and then have sat down and smoakt a Pipe, and now and then have shot a Squirrel, and not have kept up the Run, Run all day."

Nonetheless, the Lenape felt honor-bound to fulfill what they thought their ancestors had agreed to, and thus began their movement westward. The Lenape were given place after place. Each time it was promised by the government that it would be their permanent home, only to have to move again. Their trek, which lasted 130 years, finally brought them to what was known as Indian Territory, now Oklahoma. (The Delaware Tribe of Indians 2010)

This bit of history is complex and there is much that can be said about it (for additional treatments, see Fenton 1998:398-9; Kraft 1986:226-8; McConnell 1992:122; Merrell 1999; and Wallace [1949] 1990).

The topic of this paper-like the symposium for which it was initially preparedis the exchange of colonization narratives viewed in terms of what Dorothy Noyes (2006) has aptly described as a "context-sensitive philology." A "finding" of this project on the ox-hide narrative, one proposed by Barbeau and foreshadowed by all the scholars who noted the story's "old world" provenance, is the very strong likelihood that Europeans were both the source of, and motivation for, the incorporation of the ox-hide narrative into the living oral history traditions of the Woodland peoples whom I have discussed. That there is general consensus among academic historians about the facts of the Walking Purchase proves, for Woodland peoples at least, the more general validity of their tribal (or inter-tribal) historiography. Beyond this side of the story, we can also use the history/story of the Walking Purchase to speculate on the function that such narratives could play in the founding moments of colonial encounters.

The ox-hide purchase story diffused to peoples of Eastern Native North America from Europeans during the same time that Europeans were beginning to appropriate the lands of the region's Native peoples. In addition to offering Woodland Indian peoples with a retrospective explanation of one of the ways that this was done, the story seemingly also provided Europeans with a practical strategy upon which to improvise such takings in the moments that they occurred. ${ }^{33}$ Even if a cow-hide was never actually stretched and cut thinly as a means of deceiving Native landholders, the Walking Purchase makes clear that such thinking was not confined solely to the realms of popular legend among the colonial masses or the classical studies of colonial elites. For European narrators and audiences, such narratives seemingly were the aesthetic and ideological counterparts to the day-to-day realities of colonization, even as they provided, when re-keyed, the basis for Native claims to both common human decency and to the moral high ground in colonial and post-colonial North America. ${ }^{34}$

\section{The Ox-Hide Purchase as Epitomizing Event}

Whether it happened exactly the way that so many Woodland Indian narrators have reported it or not, the ox-hide story rings true with the experience of their peoples and with a world in which events like the Walking Purchase, to say nothing of pres- 
ent-day deceptions, are known facts. Finding the scholarly language with which to deal with such instances has been a central part of folkloristics' disciplinary quest, as exemplified, for instance, by the multi-generational debate on the historical validity of oral traditions (E. Basso 1990; Lowie 1915, 1917; Dixon 1915; Eggan 1967; Goldenweiser 1915; Nabokov 2002; Sturtevant 1953; Swanton 1915). There are quite a few useful frameworks within which we might think and talk further about these issues. One that has proven helpful to me, and to a number of my colleagues, is anthropologist and ethnohistorian Raymond Fogelson's notion of "epitomizing events," an idea that is just one in a series that comprises a cross-cultural typology of "events and non-events."

For Fogelson, epitomizing events are: "narratives that condense, encapsulate, and dramatize longer-term historical processes. Such events are inventions but have such compelling qualities and explanatory power that they spread rapidly through the group and soon take on an ethno historical reality of their own" (Fogelson 1989:143). ${ }^{35}$ The best-documented example of an epitomizing event in Fogelson's own work is the case of the Aní-Kutánî, a priestly class among the ancient Cherokee, who were overthrown by their own people when their rule become overly domineering. Fogelson links the story of the Aní-Kutánî to a series of other similar episodes in Cherokee historical consciousness. As narratives, these accounts all "appear to be efforts to encompass and make intelligible seemingly impersonal, inevitable, and insidious processes of change through the evocation of a real or fanciful, dramatic, epitomizing event" (Fogelson 1984:261). Reframing the cases central to his analysis, he continues:

\begin{abstract}
It is also important to emphasize that these epitomizing events involve human motivation and causation: Cherokees voluntarily accepted and then rejected the power of the Aní-Kutánî; they felt personally responsible for the smallpox plague by immorally fornicating in the fields; the extinguishing of the sacred fire was caused by the corruption of their political leaders in ceding their ancestral homelands to whites; and surely the sacred ark deserved greater protection from Delaware marauders. The Cherokees, in common with most peoples of the world, do not view history in terms of abstract, disembodied, invisible, immutable laws and forces. History is generated by human action and, since the Cherokees believe that they are not only distinctive people, but the only "real people" in the world, their past and their destiny is selfdetermined. (Fogelson 1984:261)
\end{abstract}

There are two moves here. One is understanding a different modality of history, as Barbeau began to do when he saw Mr. Kayrahoo's tale, not just as a stray bit of European folklore, but as a parable documenting and commenting on deeper truths about Wyandot colonial experience. The other, as Fogelson notes, is recognizing that the narration of such history is an active means of engaging and understanding a complicated, and often unjust, world. In the analytic language of our day, these narratives represent a confrontation between the agency of creative narrators and structures that, no matter how overwhelming and or external in origin, are still always understood in local terms, and in ways that almost always place the local at the center of the global. As Marshall Sahlins has described the task, our work is to "examine how indigenous peoples struggle to integrate the experience of the world system in some- 
thing that is logically and ontologically more inclusive: their own system of the world" (Sahlins 2000:417). ${ }^{36}$

Thus, while I agree, in essence, with Barbeau's understanding of the tale as something like a parable, my motivation in recasting this interpretation in Fogelson's terms is that doing so then places the narrative within a larger context of Woodland Indian historical consciousness rather than simply explaining it as something outside of the event- and document-centered historiography of the Western tradition. As importantly, this approach sees in the story, in its Native North American forms at least, not only the ugly domination at the center of the plot but also the creativity, resistance, cultural self-assurance, and moral indignation within which this plot is contextually enveloped in textual framing, in performance, and in local cultural meanings. Seen within a larger framework of Woodland Indian social, cultural, and historical thought, we can appreciate more fully what the story is saying, what social work it has been doing over the past several hundred years, and the ways that it has been localized to reflect enduring concerns in Woodland Indian life. ${ }^{37}$

\section{Bad News, Revisited}

In my view, among the most important contemporary contributions to the comparative study of North American Indian oral history as historical consciousness is Donald Bahr's 2001 essay "Bad News: The Predicament of Native American Mythology." This is a paper that is overflowing with provocative ideas and powerful insights born of a career-long engagement with the sacred narratives of Southwestern peoples. It is also a paper that offers a thesis (one among many) that crashes noisily and directly into the case of the ox-hide purchase and its related narratives. The project that I am beginning in this article relates so closely to the concerns of Bahr's essay that I cannot avoid engaging with his arguments, but this brings about a difficulty that must be described briefly so as to avoid misunderstanding. Bahr's essay offers many general observations on the state and nature of American Indian mythologies, including the special predicaments that these face in the life of contemporary Native communities encompassed by the larger world and the competing discourses that we are all exposed to from many corners. While Bahr's essay is a complex, interwoven whole, I have here space to touch only on the point of greatest overlap with my concerns. This does an injustice to Bahr's complex, multi-faceted argument and might mistakenly suggest that I disagree with every aspect of his position (Bahr 2001).

For Bahr, the bad news is that, while they are immeasurably rich and complex, Native American mythologies are dying; slipping into the past, despite the prestige that communities might overtly accord to them. This is so because, while beautiful creations, mythologies face a new challenge in the modern world-to defend themselves against the charge of being untrue. To complicate their fate further, to serve in modern contexts, he argues, mythologies must address themselves to Native-White relations, which, in his experience, they largely do not do (Bahr 2001).

I need to note first that, by myth, Bahr means what folklorists generally meanstories that are true to those who tell them and that serve as the basis for a coherent history of the world, one that usually begins with the events of creation. ${ }^{38}$ The hallmarks 
of Bahr's conceptualization of Native American mythology are its emphasis, crossculturally, on what he calls "Edenism," meaning events in the time before the normal order of the world was established, and "parody," which is his quite effective way of characterizing the ways that American Indian mythologies relate to one another. On this aspect, he writes: "By parody I mean 'a work that is based on another work but is cleverly different from the other and is silent about the other's existence.' In other words, to parody is to take an idea from someone else and slyly change it so as to make it your own. Instead of contesting, parodies borrow and play (Bahr 2001:588)." This view is, to my mind, a compelling recasting of the principles and findings of (Native North) Americanist folkloristics, including the foundational work of Franz Boas and his students, as well that as of Thompson and Claude Lévi-Strauss. Key here for Bahr is that parody is a different mode of cross-cultural engagement than contestation, which is the dominant means by which competing views of history engage one another in Western forms of historical consciousness.

In the context of the bad news, Bahr holds that an emphasis on Edenic themes and on parody have served to suppress "historical dispute and the narrative of recent events" (Bahr 2001:589). Like others, he sees the role of parody in mythology as central to identity formation in the context of small societies in interaction with neighbors. As for Eden, I despair trying to say all that needs to be said. The best I can do is to cite a final relevant paragraph from Bahr's account, using it as a last frame for a new comparative approach to the ox-hide purchase and its congeners. Bahr continues:

Edenism is more difficult to explain. Although I can see that all peoples may need an Eden, at least an account of ancient origins and creations, I cannot see why this should preclude literary attention to recent events. Where is the culture of resistance, which is so important to scholars of the fate of today's tribal peoples? I do not find it in native American texts from the twentieth century, at least not in those of the "old school," which were told as history and which, as explained below, I call "myths." Tentatively I say that a liking for Eden distracted the tribes away from producing an oral literature of resistance, but I cannot say why this occurred. (Bahr 2001:589)

You can probably see where I am going with this. Bahr argues that American Indian mythologies, while including prophecies of the coming of white people, generally come to a conclusion the day before Europeans arrive on the scene. This may be, as a statistical matter, a general tendency, but then the kind of comparative but contextual folklore study that is foreshadowed in the work of Fogelson and Bahr has new work to do. In light of Bahr's arguments, what do we make of the ox-hide purchase and the significantly larger corpus of first-contact and post-contact stories of which it is a part in the old narrative repertoires of Woodland Indian peoples? The generalization does not seem to hold up in this region, where contact and post-contact themes extend, almost seamlessly, the fabric of the mythology. I do not yet know why, but I think that a combination of comparative and contextual methods, old and new, when combined with the existing texts and new collaborative fieldwork, might help us find out. One set of factors that might be at play are the very different histories of contact that differentiate the experiences of Native peoples on the Eastern seaboard and in the Southwest where Bahr has worked most intensively. 


\section{Folklore Studies, Comparative Colonialisms, and a Context-Sensitive Philology}

The School of Advanced Research Press has relatively recently published a book titled Archaeology of Colonial Encounters: Comparative Perspectives in its Advanced Seminar Series. In it, a group of archaeologists struggle to re-conceptualize the way that their field approaches questions of colonization in light of the central importance accorded to studies of European colonization in many fields over the last several decades (Stein 2005). The contributors adopt a comparative frame and consider more than just the origins of the current global order; thus, they are trying to develop conceptual tools for understanding colonization in such times and places as the ancient Mediterranean and Mesopotamia and pre-European California and Mesoamerica. The challenge for them, as I think it is for folklorists, is to find ways to simultaneously pluralize the historical colonial encounters about which we speak, while preserving a middle path between, on the one hand, homogenizing such studies into a unified theory of all things colonial and, on the other hand, treating each particular case as distinct, unrelated, and incomparable.

Although the ox-hide purchase is a small bit of narrative, it has a wide reach in time and space and, as we have seen, it engages with some big and important issues in the history of human affairs. This characterization has, of course, long stood as part of folkloristics' self-understood definition of its object. In sharing some stories about this story, I have tried to continue to come to grips with what new work folklore studies might engage in now and in the future. This is a larger question of concern to many in the field. How might we preserve the accomplishments of our predecessors-the neglected comparative tools of the historic-geographic method, being just one example-while undertaking work that both incorporates all that we have struggled to learn to this point and engages with the deep human concerns, anxieties, and conflicts of our own age? What kind of stance-disciplinary, interdisciplinary, antidisciplinary, post-disciplinary-might best enable folklore studies to pursue such work with such a relationship to the field's pasts? What kind of partnerships, new or revitalized, might such work necessitate? These are among the questions that I have been asking, and I have been grateful for the chance to think and talk about them with the various interlocutors who have helped me in this project.

I wish to close by reminding myself, and you, of the human contexts that ground this work. I heard the ox-hide purchase story told most recently at sunrise on the morning of September 29, 2005. I had, at that point, been awake for twenty-seven hours. The context was the wake and funeral for a Yuchi woman whose meaning and importance to me was, and remains, indescribably large and profound. She was, among other things, one of the Yuchi women who raised me, as an exercise in charity or perhaps as a social experiment, a second time-watching out for me, feeding me, and teaching me as an adult what proper Yuchi children learn while kids. While the Sun, one manifestation of the Yuchi Creator, came over the horizon, I was assisting the eldest Yuchi chief in the preparation of the herbal medicine to be used as a purifying wash by the mourners after the funeral party returned from the grave site. The woman's husband joined us, and we sat telling stories of all sorts, as is the custom at an all-night wake among the 
Yuchi and their Woodland Indian neighbors. In the course of our conversation, the widower-who is also a friend and teacher-recounted for the chief and me the story of the ox-hide purchase. A Cherokee, he had learned it in his own community circle. For me, the moment brought back multiple memories and associations, as the woman whose passing we were marking was the daughter of the elderly Yuchi man who, in my first week as a fumbling ethnographer, had told me this story for the first time. Neither of these tellers, whose first languages are not English, had read the published texts that I have since consulted; neither had school-age lessons on Dido's founding of Carthage. The ox-hide purchase thus continues to circulate and give meaning not only to the past that it describes, but to the present in which it remains important enough to be told by smart, serious people who are concerned with both the way the world is and with determining how one might best live within it. I have been fortunate to have had teachers patient enough to try to teach me such things.

\section{Acknowledgments}

I wish to dedicate this modest contribution to the comparative enterprise to my colleague Hasan ElShamy in recognition of his fortieth year of fruitful service on the faculty of Indiana University.

Many colleagues have offered encouragement, guidance, and materials in support of this project, including Roger Abrahams, John Bierhorst, Hasan El-Shamy, Ives Goddard, Victor Golla, William H. Hansen, Sarah Iles Johnston, George E. Lankford, Randy Lewis, Adrienne Mayor, Jane McGary, Jay Miller, Tom Mould, Sadhana Naithani, Dorothy Noyes, Joshua Piker, Jim Rementer, Gregory Schrempp, and Hans-Jörg Uther. Jimmie Skeeter and Herman Tehee are among the valued teachers who have told me versions of this story. I wish to thank them and to acknowledge all of the other Woodland Indian people who have so generously shared their store of stories, experiences, and observations with me over the years. None of these good people are responsible for the mistakes I have made in using what they have so generously given to me. This paper was originally presented during a working conference titled "Colonization and Narrative Migrations: Legends of Occupation from the Mediterranean to the Americas," organized by the Center for Folklore Studies, The Ohio State University, May 12, 2006. Appreciation is extended to the colloquium participants and organizers, all of whom provided insightful commentary. Versions were also presented to the Department of Anthropology at the University of Oklahoma and, in brief, at the 2006 American Folklore Society meetings. Thanks go to my interlocutors on these occasions.

\section{Notes}

1. In the spirit of Anna Tsing's (2000) work, I would stress that, despite popular and social science rhetorics emphasizing the newness of contemporary global flows-and of what is presently called globalization more generally-global interconnections are both longstanding and, in significant part, matters of cultural circulation-a topic that has a long history as a focus for research in folkloristic and anthropological research. The historic-geographic approach in folklore, both in its Americanist (Boasian) and Finnish forms, is a key part of this genealogy.

2. In considering the contribution that folkloristics can make to interdisciplinary inquiries into colonial situations, I absolutely do not wish to suggest that important work in this domain has not already been undertaken. Numerous scholars have already contributed vitally to this project. Illustrative of the trend are works by Kirin Narayan (1993), Susan Rodgers (2003), Dorothy Noyes (2007), Donald Haase (2010), and especially Sadhana Naithani, whose investigations have been particularly fruitful and influential beyond the field (Naithani 2001, 2006, 2008, 2010). While progress has been made, I feel that Naithani's (2006:51) characterization of the field holds true: "Surprisingly few folklorists have taken up research on the relationship between colonial hegemony and oral discourse." Of course, a great body of folklore re- 
search-from Franz Boas on the Northwest Coast of North America to Henry Glassie in Northern Ireland-has been pursued in, and has meaningfully addressed, colonial contexts.

3. Standard anthropological sources on the Huron and Wyandot include Tooker ([1964] 1991), Trigger (1987), and Barbeau $(1915,1960)$. An extended bibliography of Wyandot ethnography and history can be found at http://www.kshs.org/p/american-indians-in-kansas-a-bibliography/13534\#wyandotte. For background on Barbeau, see his autobiography (Barbeau 2006), the biography by Nowry (1998), the edited collection Around and About Marius Barbeau (Jessup, Nurse, and Smith 2008) and the more focused examination of his Wyandot studies by Nurse (2001).

4. An introduction to classic, comparative folklore studies, out of which the motif and tale-type indexes emerged as research tools, can be gained in Dundes (1999). The narrative at issue in this paper was interpreted comparatively in very brief fashion by Thompson (1946:198-9). Richard M. Dorson noticed it, too, and treated it briefly in his study of "Comic Indian Anecdotes" (1946:121). For Dorson, the narrative illustrated Native people's appreciation for humorous anecdotes that portrayed the endless battle of wits staged between native and colonist. For Dorson, stories like the ox-hide purchase and the famous sale of Manhattan account provide the ground for their inverse, humorous stories of native deceptions of gullible settlers (1946:122-3).

5. In contrast to other widespread Native North American narratives, no single title, of either folk or scholarly origin, has attached to the story examined here (in the Americanist literature). Aarne and Thompson called it "The Ground Is Measured with a Horse's Skin (ox-hide)" (1981:539; this label is retained in Uther 2004:566-7). Other names include: "cowhide purchase myth" (Swanton 1928:76), "The White People Are Still Fooling Us" (Bessie Snake, quoted in Rementer 2005) and "Dido's Purchase of Carthage" (Bierhorst 1995). As noted below, no standard tale type index has yet been developed for Native North America.

6. For a classic work on the subject of first contacts, see Schieffelin and Crittenden (1991). Grumet (1995) explores Native American-European contacts in the context in Northeastern North America.

7. The reality of such intertribal leagues and their special place in Woodland history and historical consciousness is an established and important topic in the region's scholarship. Kinship terms were used for native nations whose ties to one another were expressed in the idiom of family relationships. Different groups framed each other using different kin terms at different moments, but in this system, the Delaware were often characterized as the Grandfathers to other Woodland peoples (see Trowbridge 1939:9, 55).

8. Key motifs of these contact stories include, in addition to the "ax heads as ornaments" element, the existence of prophecies that foretold the arrival of Europeans and their novel material culture, the strangeness of European ships, and varying strategies for testing the safety and effects of alcohol on first exposure.

9. Note the sense conveyed here that the Delaware felt sympathy for, and wished to extend hospitality to, the newcomers. This sensibility is easily recognizable in present-day attitudes related to hospitality among Woodland Indian communities, at least those that I know in Oklahoma. Even the most casual non-Indian visitors to Native family or community events are struck by the extent to which hospitality to strangers is prioritized as of paramount concern (see Jackson 1998).

10. Woodland norms of corporate (collective) reciprocity are shown to be at work here. Norms and forms of inter-group reciprocity are a focus in Jackson $(2003$, n.d.).

11. For the literature on Woodland Indian prophecy, see Tom Mould's contextual study of Mississippi Choctaw practices and beliefs (2003).

12. Anti-colonial wars of resistance engaged in by intertribal alliances, such as that evoked here, are now well documented in the Eastern Woodlands during the colonial and early American periods. See, for instance, Dowd (1993, 2004), Sugden (1999), and Edmunds (1983).

13. Notice that if a conventional war had been fought, without recourse to an immoral weapon of mass destruction, the allied tribes would have prevailed. For an analysis of smallpox legends and history in the Americas, see the work of Mayor (1995). As noted by Mayor (1995:n3), Dundes (1993) lamented in print that no one had yet studied legends of the intentional introduction of smallpox via blankets (Mayor's topic) or the uncorked bottle (at issue here and in many other extant texts). The vast literature in folklore studies focused on legend is beyond the scope of both this article and my competencies, but I would note that the historicity of legend is a subject taken up by Tangherlini in his (1990) survey of legend theory. 
14. A third Wyandot, Mr. Allen Johnson, served as interpreter for Barbeau's work with Mr. Kayrahoo, thus we have three Wyandots to thank, along with Barbeau, for their efforts to make this story available to us. As we pause to reflect on the people behind these narratives, I might note that the Oklahoma Wyandot community of which Mr. Johnson and Mr. Kayrahoo were a part, is that descended from those Wyandot people who moved west from Huronia, the tribal homeland at the east end of Lake Huron, over the course of the conflicts that this story encapsulates and that they resided successively in present-day Ohio, then Kansas, and finally Northeast Oklahoma (contra Nurse 2001:439) where they are located today. For a discussion of the movements of various Wyandot and Huron communities, see Tooker (1978), Heidenreich (1978), and Morissonneau (1978).

15. A different kind of analysis of a very worthwhile sort could pick up here and consider this and related texts from a discourse-centered point of view, attentive, in particular, to the questions of reported speech and "voice" (in the sense derived from the work of Mikhail Bakhtin) to which I only allude here. I have sought to contribute elsewhere to such work (performance- and discourse-oriented folkloristics and linguistic anthropology), but here I am seeking to return to, in a small way, older comparative and historical-geographic approaches in folkloristics that were, to a degree, displaced with the rise of performance-oriented research. Nonetheless, a consideration of this and related texts in discourse terms would prove most enlightening and would, I believe, further enhance our understanding of them and the colonial contexts that shape their meanings.

16. The teller was F. H. S. Knowles who "heard the tradition in England" (Barbeau 1915:26). A modern Canadian telling, used to explain the history of a cathedral built in colonial St. Johns, Newfoundland, is given in Clark (1970). To clarify the context for Barbeau's report, the Canadian Geological Survey was the organizational home for the National Museum of Man and the Canadian national research programs in anthropology and folklore studies.

17. In connection with this issue of the direction of the story's diffusion, I would note that the comparative evidence from the Woodlands region suggests that Swanton's guess that it was a recent (late nineteenth or early twentieth century) borrowing by his Creek consultants from their own schoolbooks is surely incorrect (Swanton 1928:76).

18. A full folkloristic study of the literature on the Dido legend would demand great linguistic and bibliographic skill, as well as considerable resources for translation assistance. A sense of the scale of the literature involved can be gained by doing a full text search on "Dido," "Carthage," and "hide" in the HathiTrust Digital Library or the Google Books collection. Such a search mainly just reveals the English sources. Sarah Iles Johnston and William Hansen both generously helped orient me to the sources and provided valuable leads. Not all of their assistance is reflected in this article, but their suggestions were very valuable as background for this work.

19. It may (or may not) eventually prove relevant that the Cambodian and Javanese summaries given by Frazer (1888:322) make special reference to a Dutch colonial contact situation, as do most of the Delaware examples gathered in Bierhorst's guide (1995, numbers 17, 22, 28, 40, 83, 203, 215) and studied by Rementer (2005). For accessible biographical sketches for Jacob Grimm, Reinhold Köhler, and James Frazer, see the introductory notes provided in Dundes (1999).

20. Having consulted Willoughby's text, I can note that Frazer does not distort what is reported there, although interesting details are omitted, the most relevant of which is the fact that the thong is first cut in a long, single strip, like those in the ox-hide purchase stories. I do not know if Willoughby is judged to be reliable as an ethnographer of southern Africa. A generous obituary published in Nature discusses his work (Dr. W. C. Willoughby 1938).

21. Note that in the Golden Bough, Frazer also cites one more example, not found in his previous article. This is a "Hottentot" instance that explains European settlement in South Africa. Frazer (1935:250, $\mathrm{n} 1$ ) is citing Arbousset and Daumas (1842:49). An English translation of this volume is available in Arbousset and Daumas (1846) wherein the relevant version of the ox-hide tale appears on page 25.

22. The Newfoundland instance given by Clark (1970) might be classified similarly, as it represents a victory of marginalized British colonials over the Crown.

23. The story, in this mode, recounts one expression of subaltern resistance (tricking the powerful) in the context of another (narrating a tale of resistance). In a full global study of the documented texts, it would be interesting to see what patterns are revealed. The "weak instigator" stories may be common in 
certain parts of the world relative to the "morally upright victims" stance taken in Native America. Such a pattern could correlate not only with local narrative systems and local cultures of history, but also different colonial contexts. Below I try to suggest that such comparative folkloristic work offers an opportunity for the field to engage in the larger scholarly conversation on such topics as power, resistance, hegemony, imperialism, and colonialism, and what James C. Scott (1987) referred to as "everyday forms of peasant resistance."

24. The relevant motifs for "Deceptive Land Purchase" in Thompson (1955-58) begin with K185.1 (the "ox-hide measure") and continue through many variations on the theme K185.2 through K185.14. I hope that an enterprising scholar will take up the whole corpus.

25. Jim Rementer has noted for me that the notion of kwulakan centered on "food over which there has been an argument or dispute, but that [Mrs. Dean] thought the concept might be extended to anything that became taboo" (Rementer, personal communication).

26. The, as yet, unrealized dream of a tale type index for Native America is too large a topic to explore here. Americanists have discussed the problem for generations and continue to rely, for the time being, on a "catchword" system, although it is possible to use the numbering and naming scheme developed in Claude Lévi-Strauss's work on mythology, particularly the Mythologiques (1969, 1973, 1978, 1981), as a common frame of reference for the narratives discussed therein. For the catchword system and the hope for a proper "Concordance of American Myth," key sources include Swanton (1907, 1910), Thompson ([1929] 1966:271-2) and the valuable documentary history authored by Darnell (1973). Very useful in this connection is also Dundes (1963). Jacobs (1966) is a brutally harsh assessment of "oral literature" studies that touches upon this specific matter from a different point of view. While a tale type index has not been completed, Thompson ([1929] 1966) provides a rich start to such an effort and has often been used as a provisional index. While also a provisional effort (and not containing a discussion of AT 2400/ ATU 927C*), Remedios S. Wycoco's (1951) neglected dissertation on American Indian tale types should be mentioned in this connection as well. For England and North America in general, see the tale type and motif index developed by Baughman (1966). For type 2400 and Motif K185.1, Baughman noted two English examples and the Woodland Indian ones cited by Dorson (1946).

27. Rementer reports that elder Nora Thompson Dean, drawing upon Delaware oral tradition, recounted the story in a presentation for an academic audience in 1980. Present for the event, he recalls an unknown professor smugly commenting that the story was the Dido tale and asking "what do you think of that?" Rementer reports that she replied simply: "nothing." Rementer recalls that: "Soon Herb [Herbert C.] Kraft got up and said the Delaware probably learned the story because some whites had tried it on them." Kraft was a specialist in the study of Delaware history and archaeology (Rementer, personal communication).

28. Bierhorst treats the ox-hide purchase, which he names "Dido's Purchase of Carthage" and the "Land Sale with Chair Deception" as separate, but related motifs. I suspect that, had the "Land Sale with Chair Deception" been widely known to the Europeanist folklorists, they would have grouped it with the OxHide Purchase (as part of K185, for instance). Another text attributed to the Wyandot (Woodman 1924:711) also situates the coastal encounter among the Delaware and focuses on the unwound chair incident. I do not understand the documentary context of this text (which was one of two used by Dorson 1946:121), but it enriches the corpus under consideration.

29. As partial and suggestive evidence of this proposition, see Shawnese Traditions: C. C. Trowbridge's Account, an early nineteenth-century manuscript edited for publication by Vernon Kinietz and Erminie W. Voegelin (Trowbridge 1939). Trowbridge, who possessed considerable knowledge of the native peoples of the region, recorded a Shawnee account that contained all of the major elements found in the Wyandot and Delaware narratives. Trowbridge, who knew all three peoples (and others to whom they were allied), wrote: "They [the Shawnee] say that no other nation was with them upon the arrival of the whites, notwithstanding the Wyandots \& Delawares both tell the same story in substance" (10). In an editorial note at this point in Trowbridge's account, Kinietz and Voegelin acknowledge, "This tale is of Old World origin" (n6).

30. Based on discussion given in Dorson (1946:121), it at first appeared that the story had also been documented among the Micmac. As the Micmac of Eastern Canada are a coastal Algonkian speaking people (like the Delaware), this would have fit neatly with the regional patterning discussed here. Dorson's 
source is Mabel Burkholder (1923:20-3). Her work is a popular literary anthology that shows (without discussion), the signs of heavy intervention by the editor/author. (She writes (1923:7) of "gathering" legends from "all parts of Canada" but the work does otherwise signal its status as an edited volume.) In the case of the ox-hide purchase tale, close comparison indicates that Mr. Kayrahoo's story as recorded and published by Barbeau is her unnamed source. I believe that she substituted the Micmac in place of the Delaware so as to achieve her evident literary goal of producing a Canadian anthology. The story may be told among the Micmac, but I do not have access to a reliable source on this point.

31. The link that I am making here between the "legend" of the ox-hide purchase and the "history" of the Walking Purchase was made before me by Eugene S. McCartney (1927). I learned this after making the connection on my own.

32. The author of this account is Jim Rementer, who composed it on behalf of the tribe. I appreciate his allowing me to reprint the material here.

33. Shakespeare scholar David Scott Wilson-Okamura has pointed to the ways that Dido's colonization at Carthage served the real poetic, rhetorical, and political purposes of early modern colonial leaders, including on the eastern seaboard on North America. He also tracks the movement of such Virgilian themes into Shakespeare's The Tempest (Wilson-Okamura 2003:716).

34. Historian Joshua Piker has noted that, in addition to enabling native peoples to claim the moral high ground in the colonial encounter, stories like the ox-hide purchase also serve to illustrate the validity and accuracy of indigenous traditions of prophecy. This theme is particularly present in Mr. Kayrahoo's text. Both effects are a part of a more complex notion of resistance, one that goes beyond the kind of military resistance that Mr. Kayrahoo describes in his narrative (personal communication).

35. Folklorist George E. Lankford-a scholar who has given extensive consideration to themes such as those raised in this paper-has fruitfully suggested that the category of "cliché-legend" might also capture the nature of stories such as the ox-hide purchase that I am considering here via Fogelson's model of epitomizing event. Lankford suggests that under some circumstances, a "historical account is not as desirable in continuing narrative traditions as a generalized legendary account that can represent the actual event." Using the example of Ozark narratives of Civil War era violence (drawing on Johnston 1976), Lankford has developed a compelling account for the motivations that would explain a preference for a diffuse legend over a tight, historically specific narrative (personal communication via the Journal of American Folklore editors). It is hoped that Lankford can develop his case for cliché-legend in future published work. He has also very rightfully recognized that the ox-hide purchase narrative, as an example of first-contact narrative with something of an absurd character, partakes in the spirit of Trickster narratives that are highly developed throughout Native North America. Like the white men in the ox-hide purchase, the Trickster is powerful but also both absurd and immoral. Lankford argues, quite rightfully I think, that only a Trickster-like being would get away with such an amoral and outlandish scheme as that described in the ox-hide purchase. In Lankford's account, the Trickster provides a model for the difficult task of making sense of the "white man." The literatures on Tricksters and on crazy white people are too vast to cite, but consider Radin (1956) and Keith Basso (1979).

36. For applications of Fogelson's model of "events and non-events," see a number of the chapters gathered in Kan and Strong (2006). Without much elaboration, I framed the Yuchi version of the ox-hide purchase in this way in Jackson (2003:22-3). Noyes has usefully noted that while the kind of acceptance of responsibility for tragedy that Fogelson is chronicling here does represent a kind of assertion of agency in the face of overwhelming structural realities, it also constitutes a means of denying the power of such impersonal forces. Moving from a culturalist analysis to a personalist one, she recognizes something similar in Anglo-American personal narratives in which it is easier to claim responsibility for failures than to face a sense of powerlessness that comes from accepting that there are things in every life that are beyond our individual control (personal communication). Much more could be done with the theoretical issues raised by these materials.

37. It should be clear that I feel that this story deserves further study. This would require, of course, going back and looking at the particular texts with an eye on the specific details in light of the local cultural contexts. Additional work would also be enhanced by performance analyses of actual enactments of the story in community contexts.

Another valuable tack to take in considering such stories will be to follow the lead provided by Hasan 
El-Shamy (1995:xiii, 1997) in his work on narrative, and Noyes (2003) in her studies of festival, and recognize that narratives such as the ox-hide story can be viewed as important expressions of vernacular social theorizing. In this case we might glimpse in the ox-hide story a fragment of an indigenous theory of colonialism as social process.

38. Bahr is actually much more interesting than this in his conception of myth, which also acknowledges that whoever uses the word "myth" is positioning her/himself as a disbeliever relative to someone else who is held to believe the story in question, who, in other words sees it as history (Bahr 2001:589-90).

\section{References Cited}

Aarne, Antti, and Stith Thompson. 1981. The Types of the Folktale: A Classification and Bibliography. FF Communications 184 (2nd revision). Helsinki: Suomalainen Tiedeakatemia.

Arbousset, Thomas, and François Daumas. 1842. Relation d'un voyage d'exploration au nord-est de la colonie du Cap de Bonne-Espérance. Paris: Arthus Bertrand.

1846. Narrative of an Exploratory Tour to the North-east of the Colony of the Cape Good Hope by the Revs. T. Arbousset and F. Daumas of the Paris Missionary Society, trans. John Croumbie Brown. Cape Town, South Africa: A. S. Robertson, Heerengracht, Solomon. http://hdl.handle.net/2027/ nyp.33433082327390.

Bahr, Donald. 2001. Bad News: The Predicament of Native American Mythology. Ethnohistory 48(4):587612.

Barbeau, Marius. 1915. Huron and Wyandot Mythology. Canada Department of Mines, Geological Survey Memoir 80, Anthropological Series 11. Ottawa: Government Printing Bureau. http://hdl.handle .net/2027/uc1.32106000740347.

. 1960. Huron-Wyandot Traditional Narratives, in Translations and Native Texts. National Museum of Canada, Bulletin 165, Anthropological Series 47. Ottawa: Queen's Printer.

- 2006. Marius Barbeau: A Canadian Hero and his Era, 1883-1969. Canadian Museum of Civilization. http://www.civilization.ca/cmc/exhibitions/tresors/barbeau/mbh0000e.shtml. [The page cited is actually this one: http://www.civilization.ca/cmc/exhibitions/tresors/barbeau/mbh0800e.shtml.]

Basso, Ellen B. 1990. The Last Cannibal. Journal of Folklore Research 27(1-2):133-73.

Basso, Keith H. 1979. Portraits of "The Whiteman": Linguistic Play and Cultural Symbols among the Western Apache. New York: Cambridge University Press

Baughman, Ernest Warren. 1966. Type and Motif-Index of the Folktales of England and North America. Indiana University Folklore Series 20. The Hague: Mouton.

Bierhorst, John. 1995. Mythology of the Lenape: Guide and Texts. Tucson: University of Arizona Press.

Boon, James A. 1977. The Anthropological Romance of Bali, 1597-1972: Dynamic Perspectives in Marriage and Caste, Politics and Religion. New York: Cambridge University Press.

Burkholder, Mabel. 1923. Before the White Man Came: Indian Legends and Stories. Toronto, Canada: McClelland and Stewart.

Clark, Raymond J. 1970. A Classical Foundation-Legend from Newfoundland. Folklore 81(3):182-4.

Darnell, Regna. 1973. American Anthropology and the Development of Folklore Scholarship: 1890-1920. Journal of the Folklore Institute 10(1-2):23-39.

Delaware Tribe of Indians. 2010. The Walking Purchase. http://culture.delawaretribe.org/walkingpurchase .htm.

Dinwoodie, David. 2006. Time and the Individual in Native North America. In New Perspectives on Native North America: Cultures, Histories, and Representations, ed. Sergei A. Kan and Pauline Turner Strong, pp. 327-48. Lincoln: University of Nebraska Press.

Dixon, R. B. 1915. Dr. Dixon's Reply. American Anthropologist 17(3):599-600. http://onlinelibrary.wiley .com/doi/10.1525/aa.1915.17.3.02a00200/abstract.

Dorson, Richard M. 1946. Comic Indian Anecdotes. Southern Folklore Quarterly 10(2):113-28.

Dowd, Gregory Evans. 1993. A Spirited Resistance: The North American Indian Struggle for Unity, 17451815. Baltimore, MD: Johns Hopkins University Press. 
2004. War under Heaven: Pontiac, the Indian Nations, and the British Empire. Baltimore, MD: Johns Hopkins University Press.

Dr. W. C. Willoughby. Obituary. 1938. Nature 142(3589):282.

Dundes, Alan. 1963. Review: Indian Tales of North America by Tristan P. Coffin. Journal of American Folklore 76(299):69-71.

. 1993. Preface. In Contemporary Legend, ed. Paul Smith and Gillian Bennett, pp. ix-xiii. New York: Garland.

Dundes, Alan, ed. 1999. International Folkloristics: Classic Contributions by the Founders of Folklore. Lanham, MD: Rowman \& Littlefield.

Eck, Rutger van. 1880. Schetsen van het eiland Bali [Sketches of the Island of Bali]. Tijdschrift voor Nederlandsch Indië 9(1):1-39.

Edmunds, R. David. 1983. The Shawnee Prophet. Lincoln: University of Nebraska Press.

Eggan, Fred. 1967. From History to Myth: A Hopi Example. In Studies in Southwestern Ethnolinguistics, ed. Dell Hymes, pp. 33-53. The Hague, Netherlands: Mouton.

Ellmann, Richard. 1983. James Joyce (revised edition). New York: Oxford University Press.

El-Shamy, Hasan M. 1995. Folk Traditions of the Arab World: A Guide to Motif Classification. Vol. 1. Bloomington: Indiana University Press.

- 1997. Psychologically-Based Criteria for Classification by Motif and Tale Type. Journal of Folklore Research 34(3):233-43.

Fenton, William N. 1998. The Great Law and the Longhouse: A Political History of the Iroquois Confederacy. Norman: University of Oklahoma Press.

Fogelson, Raymond D. 1984. Who Were the Aní-Kutánî? An Excursion into Cherokee Historical Thought. Ethnohistory 31(4):255-63.

- 1989. The Ethnohistory of Events and Nonevents. Ethnohistory 36(2):133-47.

Frazer, James G. 1888. Hide-Measured Lands. Classical Review 2(10):322.

- 1935. The Golden Bough: A Study in Magic and Religion. Part 4: Adonis Attis Osiris, Vol. 2 (3rd edition). New York: Macmillan. http://hdl.handle.net/2027/mdp.39015005121481.

Goddard, Ives. 1978. Delaware. In Handbook of North American Indians. Vol. 15: Northeast, ed. Bruce Trigger, pp. 213-39. Washington, DC: Smithsonian Institution.

Goldenweiser, A. A. 1915. The Heuristic Value of Traditional Records. American Anthropologist 17(4):7634. http://onlinelibrary.wiley.com/doi/10.1525/aa.1915.17.4.02a00220/abstract.

Grimm, Jacob. 1881. Deutsche Rechtsalterthümer (3rd edition). Göttingen, Germany: Dieterich.

Grumet, Robert S. 1995. Historic Contact: Indian People and Colonists in Today's Northeastern United States in the Sixteenth through Eighteenth Centuries. Norman: University of Oklahoma Press.

Haase, Donald. 2010. Decolonizing Fairy-Tale Studies. Marvels and Tales 24(1):17-38.

Hallowell, A. Irving. 1942. Some Psychological Aspects of Measurement among the Saulteaux. American Anthropologist. 44(1):62-77. http://onlinelibrary.wiley.com/doi/10.1525/aa.1942.44.1.02a00070/ abstract.

Heidenreich, Conrad E. 1978. Huron. In Handbook of North Americas. Vol. 15: Northeast, ed. Bruce Trigger, pp. 368-88. Washington, DC: Smithsonian Institution.

Jackson, Jason Baird. 1998. Architecture and Hospitality: Ceremonial Ground Camps and Foodways of the Yuchi Indians. Chronicles of Oklahoma 76(2):172-89.

1999. Indian Territory as a Model of Woodland Social History. Paper presented at the American Society for Ethnohistory Meetings, October 21, Mashantucket, Connecticut.

- 2003. Yuchi Ceremonial Life: Performance, Meaning, and Tradition in a Contemporary American Indian Community. Lincoln: University of Nebraska Press.

. 2006. Tracing the Distribution of a Folktale Motif. SSILA Newsletter 24(4):3.

- n.d. The Creator's Ways: Histories of Ritual and Rituals of History among the Yuchi and their Neighbors. Manuscript in the author's possession.

Jackson, Jason Baird, and Raymond D. Fogelson. 2004. Introduction. In Handbook of North American Indians. Vol. 14: Southeast, ed. Raymond D. Fogelson, pp. 1-13. Washington, DC: Smithsonian Institution. 
Jacobs, Melville. 1966. A Look Ahead in Oral Literature Research. Journal of American Folklore 79(313):413-27.

Jessup, Lynda, Andrew Nurse, and Gordon E. Smith, eds. 2008. Around and About Marius Barbeau: Modeling Twentieth-Century Culture. Mercury Series, Cultural Studies Paper 83. Gatineau, QC: Canadian Museum of Civilization.

Johnston, James J. 1976. Jayhawker Stories: Historical Lore in the Arkansas Ozarks. Mid-South Folklore 4:3-10.

Kan, Sergei A., and Pauline Turner Strong, eds. 2006. New Perspectives on Native North America: Cultures, Histories, and Representations. Lincoln: University of Nebraska Press.

Köhler, Reinhold. 1864. Sagen von Landerwerbung durch zershnittene Häute. Orient und Occident 3:185-7.

. 1900. Kleinere Schriften von Reinhold Köhler. Vol. 2, ed. Johannes Bolte, pp. 319-21. Weimar, Germany: Verlag von Emil Felber.

Kraft, Herbert C. 1986. The Lenape: Archaeology, History and Ethnography. Newark: New Jersey Historical Society.

Lévi-Strauss, Claude. 1969. The Raw and the Cooked, trans. John and Doreen Weightman. New York: Harper and Row.

- 1973. From Honey to Ashes, trans. John and Doreen Weightman. New York: Harper and Row.

- 1978. The Origin of Table Manners, trans. John and Doreen Weightman. New York: Harper and Row.

- 1981. The Naked Man, trans. John and Doreen Weightman. New York: Harper and Row.

Linn, Mary S., and Jason Baird Jackson. 2004. Yuchi Trickster Tales. In Voices from Four Directions: Contemporary Translations of the Native Literatures of North America, ed. Brian Swann, pp. 368-82. Lincoln: University of Nebraska Press.

Lowie, Robert. 1915. "Oral Tradition and History." American Anthropologist 17(3):597-9. http://onlinelibrary .wiley.com/doi/10.1525/aa.1915.17.3.02a00190/abstract.

—. 1917. "Oral Tradition and History." Journal of American Folklore 30(116):161-7.

Mayor, Adrienne. 1995. The Nessus Shirt in the New World: Smallpox Blankets in History and Legend. Journal of American Folklore 108(427):54-77.

McCartney, Eugene S. 1927. Popular Methods of Measuring. Classical Journal 22(5):325-44.

McConnell, Michael N. 1992. A Country Between: The Upper Ohio Valley and Its Peoples, 1724-1774. Lincoln: University of Nebraska Press.

Merrell, James H. 1999. Into the American Woods: Negotiators on the Pennsylvania Frontier. New York: Norton.

Miller, Jay. 1975. Kwulakan: The Delaware Side of Their Movement West. Pennsylvania Archaeologist 45(4):45-6.

Morissonneau, Christian. 1978. Huron of Lorette. In Handbook of North Americas. Vol. 15: Northeast, ed. Bruce Trigger, pp. 389-93. Washington, DC: Smithsonian Institution.

Mould, Tom. 2003. Choctaw Prophecy: A Legacy for the Future. Tuscaloosa: University of Alabama Press. Nabokov, Peter. 2002. A Forest of Time: American Indian Ways of History. New York: Cambridge University Press.

Naithani, Sadhana. 2001. An Axis Jump: British Colonialism in the Oral Folk Narratives of NineteenthCentury India. Folklore 112(2):183-8.

- 2004. [Excerpt from] Colonial Hegemony and Oral Discourse. Indian Folklife 3(2):10. http://www .wiki.indianfolklore.org/images/a/a4/Ifl_15.pdf.

- 2006. Colonial Hegemony and Oral Discourse. In Folklore as Discourse, ed. M. D. Muthukumaraswamy, pp. 50-60. Chennai, India: National Folklore Support Centre.

- 2008. Colonialism. In Greenwood Encyclopedia of Folktales and Fairy Tales. Vol. 1, ed. Donald Hasse, pp. 222-6. Westport, CT: Greenwood.

- 2010. The Story-Time of the British Empire: Colonial and Postcolonial Folkloristics. Jackson: University Press of Mississippi.

Narayan, Kirin. 1993. Banana Republics and V. I. Degrees: Rethinking Indian Folklore in a Postcolonial World. Asian Folklore Studies 52(1):177-204. 
Nowry, Laurence. 1998. Man of Mana: Marius Barbeau, a Biography. Toronto, Canada: NC Press.

Noyes, Dorothy. 2003. Fire on the Plaça: Catalan Festival Politics after Franco. Philadelphia: University of Pennsylvania Press.

- 2006. "Colonization and Narrative Migrations." [Conference prospectus for an event held May 12, 2006, at The Ohio State University under the sponsorship of the Center for Folklore Studies at The Ohio State University.] http://cfs.osu.edu/activities/conferences/fy2006/colonization_narrative.

. 2007. Voice in the Provinces: Submission, Recognition, and the Making of Heritage. In Prädikat "Heritage": Wetschöpfungen aus kulturellen Ressourcen, ed. Dorothee Hemme, Markus Tauschek, and Regina Bendix, pp. 33-52. Berlin, Germany: Lit Verlag.

Nurse, Andrew. 2001. "But Now Things Have Changed": Marius Barbeau and the Politics of Amerindian Identity. Ethnohistory 48(3):433-72.

Oxford English Dictionary Online. 1989 (2nd edition). Oxford, Eng.: Oxford University Press. http://www .oed.com/viewdictionaryentry/Entry/86719 (accessed June 11, 2012).

Powell, J. U. 1933. Byrsa, the Bull's Hide, at Carthage, and Some Parallels. Folklore 44(3):310-5.

Radin, Paul. 1956. The Trickster: A Study of Native American Mythology. New York: Philosophical Library. Rementer, Jim. 2005. The Arrival of the Whites. In Algonquian Spirit: Contemporary Translations of the Algonquian Literatures of North America, ed. Brian Swann, pp. 49-61. Lincoln: University of Nebraska Press.

Rodgers, Susan. 2003. Folklore with a Vengeance: A Sumatran Literature of Resistance in the Colonial Indies and New Order Indonesia. Journal of American Folklore 116(460):129-58.

Rose, H. J. 1929. A Handbook of Greek Mythology, Including Its Extension to Rome. New York: Dutton.

Sahlins, Marshall. 2000. Cosmologies of Capitalism: The Trans-Pacific Sector of "The World System." In Culture in Practice: Selected Essays, pp. 415-69. New York: Zone Books.

Schieffelin, Edward L., and Robert Crittenden. 1991. Like People You See in a Dream: First Contact in Six Papuan Societies. Stanford, CA: Stanford University Press.

Scott, James C. 1987. Weapons of the Weak: Everyday Forms of Peasant Resistance. New Haven, CT: Yale University Press.

Stein, Gil, ed. 2005. Archaeology of Colonial Encounters: Comparative Perspectives. Santa Fe, NM: School of American Research Press.

Sturtevant, William C. 1953. Chakaika and the "Spanish Indians": Documentary Sources Compared with Seminole Tradition. Tequesta 13:35-73. http://digitalcollections.fiu.edu/tequesta/files/1953/53_1_03 .pdf.

Sugden, John. 1999. Tecumseh: A Life. New York: Holt.

Swanton, John R. 1907. A Concordance of American Myths. Journal of American Folklore 20(78):220-2. - 1910. Some Practical Aspects of the Study of Myths. Journal of American Folklore 23(87):1-7.

. 1915. Dr. Swanton's Reply. American Anthropologist 17(3):600. http://onlinelibrary.wiley.com/ doi/10.1525/aa.1915.17.3.02a00210/abstract.

. 1928. Social Organization and Social Usages of the Indians of the Creek Confederacy. In FortySecond Annual Report of the Bureau of American Ethnology, pp. 23-472. Washington, DC: Government Printing Office. http://www.archive.org/details/annualreportofbu42smithso.

Tangherlini, Timothy. 1990. "It Happened Not Too Far From Here ...": A Survey of Legend Theory and Characterization. Western Folklore 49(4):371-90.

Thompson, Stith. [1929] 1966. Tales of the North American Indians. Bloomington: Indiana University Press.

- 1946. The Folktale. New York: Holt, Rinehart and Winston. http://hdl.handle.net/2027/inu .30000006134963

-1955-58. Motif-Index of Folk-Literature: A Classification of Narrative Elements in Folktales, Ballads, Myths, Fables, Mediaeval Romances, Exempla, Fabliaux, Jest-Books and Local Legends (revised and enlarged edition). Bloomington: Indiana University Press. [Electronic version published as part of the Past Masters Database, Charlottesville, VA: IntelLex Corporation, 2000]

Tolstoy, Leo. 1993. How Much Land Does a Man Need? and Other Stories, trans. Ronald Wilks. New York: Penguin. 
Tooker, Elisabeth. [1964] 1991. An Ethnography of the Huron Indians, 1615-1649. Syracuse, NY: Syracuse University Press.

. 1978. Wyandot. In Handbook of North Americas. Vol. 15: Northeast, ed. Bruce Trigger, pp. 398-406. Washington, DC: Smithsonian Institution.

Trigger, Bruce. 1987. Children of Aataentsic: A History of the Huron People to 1660. Montreal: McGillQueen's University Press.

Trowbridge, C. C. 1939. Shawnese Traditions: C. C. Trowbridge's Account. Occasional Contributions from the Museum of Anthropology of the University of Michigan 9, ed. Vernon Kinietz and Erminie W. Voegelin. Ann Arbor: University of Michigan Press.

Tsing, Anna. 2000. The Global Situation. Cultural Anthropology 15(3):327-60.

Urban, Greg, and Jason Baird Jackson. 2004. Mythology and Folklore. In Handbook of North American Indians. Vol. 14: Southeast, ed. Raymond D. Fogelson, pp. 707-19. Washington, DC: Smithsonian Institution.

Uther, Hans-Jörg. 2004. The Types of International Folktales: A Classification and Bibliography, Based on the System of Antti Aarne and Stith Thompson. Part 1: Animal Tales, Tales of Magic, Religious Tales, and Realistic Tales, with an Introduction. FF Communications 284. Helsinki, Finland: Suomalainen Tiedeakatemia.

Virgil. 1995. The Aeneid, trans. Charles J. Billson. New York: Dover.

Wagner, Günter. 1931. Yuchi Tales. Publications of the American Ethnological Society 13. New York: G. E. Stechert.

Wallace, Anthony F. C. [1949] 1990. King of the Delawares: Teedyuscung, 1700-1763. Syracuse, NY: Syracuse University Press.

Waselkov, Gregory A., with a contribution by Jason Baird Jackson. 2004. Exchange and Interaction since 1500. In Handbook of North American Indians. Vol. 14: Southeast, ed. Raymond D. Fogelson, pp. 689-96. Washington, DC: Smithsonian Institution.

Willoughby, W. C. 1905. Notes on the Totemism of the Becwana. Journal of the Anthropological Institute 35(July-December):295-314.

Wilson-Okamura, David Scott. 2003. Virgilian Models of Colonization in Shakespeare's Tempest. English Literary History 70(3):709-37.

Woodman, J. J. 1924. Indian Legends, Being a Choice Collection of the Best Legends, Stories, and Traditions as Told by the Warrior and the Squaw to the Papoose and Showing How the Young Indian of the Olden Time Was Educated, to which is Added Some Personal Narratives of Indian Captivity as Related by the Unfortunate Survivors. Boston, MA: Stratford.

Wycoco, Remedios S. 1951. The Types of North-American Indian Tales. PhD diss., Indiana University. 